\title{
Los materiales vitrocerámicos en la construcción
}

\section{Glass-ceramics as building materials}

Fecha de recepción: 4-III-96

Fecha de aceptación: 20 III-96
J. M RINCÓN y M. ROMERO

Lab. Materiales Vitrocerámicos. IETCC-CSIC, Madrid

ESPAÑA

\section{RESUMEN}

Los productos o materiales vitrocerámicos se componen, como cualquier material de tipo cerámico, de una o varias fases cristalinas embebidas en una matriz amorfa o vitrea, pero cuyo proceso de fabricación implica la desvitrificación o nucleación y cristalización controlada de un vidrio original o de partida. En el proceso de obtención de estos materiales se puede conservar la forma original conferida al vidrio de partida por los métodos convencionales de moldeado de vidrios (procesado vitrocerámico propiamente dicho), o se puede conservar la forma de la mezcla de materias primas fundidas, cristalizando el fundido por enfriamiento lento (procesado de tipo petrúrgico) o bien, sinterizar y, al mismo tiempo cristalizar, el vidrio de partida en forma de frita o granilla (procesado de vitrocerámicos por sinterización).

En cada uno de estos procesos, que son perfectamente asequibles a escala industrial, se pueden obtener unos materiales transparentes y opacos, con o sin color que, con un diseño adecuado de composición y microestructura, tienen numerosas aplicaciones domésticas, industriales y arquitectónicas. Se trata, en este caso, de resaltar las posibilidades de uso de estos materiales en la Industria de la Construcción como pavimentos, revestimientos y elementos decorativos. De hecho, su uso está muy extendido en paises del Este Europeo y Japón, especialmente en aplicaciones arquitectónicas en grandes superficies.

La mayor ventaja del proceso vitrocerámico es que, debido al propio proceso de vitrificación de partida que implica su obtención, permite incorporar en su composición numerosos residuos mineros $e$ industriales, tales como escorias, cenizas volantes, lodos o fangos... que pueden, de esta manera, no sólo ser inertizados, sino, además, convertirse, sin riesgo para el medio ambiente, en materias primas útiles para fabricar nuevos productos, ofreciendo al arquitecto y al decorador una nueva gama de "ecomateriales", con múltiples posibilidades complementarias de los materiales arquitectónicos ya existentes en el mercado.

\begin{abstract}
SUMMARY
Glass-ceramics are materials composed as any ceramic material by several crystalline phases embedded in an amorphous or vitreous matrix, but their manufacture process implies the controlled devitrification or nucleation and growth of phases from an original glass. The original shape of the original glass moulded by conventional methods is carried out by using pressing and sintering followed by crystallization steps.
\end{abstract}

By both processing routes are obtained transparent and or opaque materials, with or without colours, which after adequate control and design of composition and microstructure have numerous domestic and architectonic applications. They can be used as paviments or wall coatings and in various decorative elements. In fact, their use is very extensive in east- european, american and asian (Japan) countries in constructions for covering large surfaces.

The greater advantage of the glass-ceramic process is that due to the own process of vitrificacion allows the incorporation in their structure of a wide range of compositions from mining and industrial residues, such as red muds, ashes, fangos, scraps... which they can in this way not only be inertizated, but furthermore it be converted without risk for the environment into products useful in construction applications, offering to the architect and to the decorator a new range of "eco-materials" with multiple complementary possibilities of the already existing architectural materials in the market. 


\section{INTRODUCCIÓN}

La nucleación y cristalización pueden definirse como los procesos térmicos y cinéticos en virtud de los cuales, a partir de una fase estructuralmente desordenada, se forma una fase sólida estable con una ordenación geométrica regular. Este proceso de ordenación, es consecuencia de una disminución de la energía libre del sistema cuando un fundido es enfriado por debajo de su temperatura de líquidus $\left(\mathrm{T}_{\mathrm{L}}\right)$.

Como los vidrios o sustancias vítreas se encuentran "congelados" en estado de subenfriamiento, con un contenido energético mayor que el equilibrio termodinámico (1), pueden evolucionar en condiciones favorables para formar especies cristalinas estables.

Este fenómeno se conoce con el nombre de Desvitrificación, ya que constituye un fenómeno que se opone a la propia naturaleza del vidrio.

Las bases científicas sobre la cristalización de líquidos subenfriados fueron establecidas por Tamman (2), cuyas investigaciones pusieron de manifiesto la existencia de las dos etapas principales que determinan el proceso de desvitrificación: Nucleación o formación de gérmenes cristalinos y Cristalización o desarrollo de los cristales. Pero es, en las décadas entre 1960 y 1980 , cuando las teorías generales sobre nucleación y cristalización en vidrios quedaron establecidas, debido a la importancia que adquiere el control del proceso de desvitrificación en la producción de materiales vitrocerámicos o vitrocristalinos $(3,4)$. De esta forma, lo que en un principio eran procesos no deseables en la obtención de vidrios, ya que daba lugar a defectos, se ha transformado en un mecanismo indispensable para obtener materiales cerámicos con propiedades tecnológicas útiles.

\section{EL PROCESO VITROCERÁMICO}

El proceso vitrocerámico supone la obtención inicial de un vidrio, a partir del cual, mediante tratamientos térmicos de nucleación y cristalización, se obtienen materiales vitrocristalinos con una microestructura y propiedades determinadas, que están en función de la composición química original y de las aplicaciones posteriores de dicho material (4). Es, pues, evidente que de todo el proceso vitrocerámico el control de la desvitrificación, es decir, el control de la nucleación y la cristalización del vidrio de partida, es el aspecto más delicado del mismo. La desvitrificación controlada de un vidrio depende, además de otros factores estructurales y composicionales, de su comportamiento termodinámico y cinético, el cual determinará los ciclos térmicos más adecuados que hay que aplicar en cada caso para llegar a obtener el material final que se desea.

\section{INTRODUCTION}

The nucleation and crystallization can be defined as the thermal and kinetic processes by virtue of those which, as of a structurally amorphous phase, is formed in a stable solid phase with a regular geometric shape. This ordering process, it is consequence of a decrease of free energy of the system when a molten glass is cooled below its liquid temperature $\left(T_{L}\right)$

When the glasses or vitreous substances are found " freezed "in state of supercooling with an energetic content greater than the thermodynamic balance (1). they can evolve in favorable conditions to form stable crystalline phases. This phenomenon is known with the name of Devitrification, since constitutes a phenomenon that is opposed to the own nature of the glass.

The scientific bases on the supercooled liquids were established by Tamman (2), whose investigations showed the existence of the two principal stages that determine the process of devitrification : Nucleation + crystallization or growth of crystalline nucleus and crystallization or development of the crystals. But it is in the decades between 1960s and 1980 when the general theories on nucleation and crystallization in glasses were established.

due to the importance that acquires the control of the devitrification process in the glass-ceramics production $(3,4)$. In this way what in a principle were not desirable processes in the glasses obtention, since produce defects, it has been transformed into an indispensable mechanism to obtain ceramic materials with useful technological properties.

\section{THE GLASS-CERAMICS PROCESS}

The glass-ceramics process implies the initial obtention of a glass, from which, through thermal treatments of nucleation and crystallization, are obtained glass-ceramics with a microstructure and properties, that they are function of the original chemical composition and of the subsequent applications of these materials (4). Therefore, it is evident that of the all the glass-ceramic process, that is to say the control of the nucleation and the crystallization of the original glass, it is the most critical aspect of the process. The controlled devitrification of a glass depends, in addition to other structural factors of their thermodynamic and kinetic behavior, which will determine the most adequate thermal cycles than one must to apply in each case to obtain the final glass-ceramics material. 
Los mecanismos por los que se produce la nucleación de un vidrio pueden ser de tipo homogéneo, si es a partir de los propios constituyentes del fundido, o de tipo heterogéneo, si la nucleación se desarrolla a partir de partículas con diferente composición química o sobre las interfases determinadas por las superficies que limitan al fundido.

Desde el punto de vista cinético, las velocidades de nucleación y cristalización presentan sendos intervalos máximos de desarrollo respecto a la temperatura, (Fig. 1). La velocidad de nucleación depende, además de la probabilidad de formación de núcleos estables, de la difusión de los distintos constituyentes necesarios para el desarrollo del núcleo. Asimismo, la velocidad de crecimiento cristalino también se ve influida por la capacidad de transporte de los componentes químicos hasta el cristal en desarrollo.

Del estudio experimental de la variación de la viscosidad frente a la temperatura, pueden definirse una serie de intervalos delimitados por puntos de viscosidad fija y que, en buena medida, condicionan los procesos de desvitrificación controlada. En líneas generales, para conseguir una nucleación efectiva, la temperatura óptima de nucleación debe situarse dentro del intervalo térmico correspondiente a un valor de la viscosidad igual a $10^{11}-10^{12} \mathrm{dPas}$, es decir, temperaturas ligeramente superiores a la temperatura de transformación vítrea $(\mathrm{Tg})$, la cual representa la frontera entre el estado rígido y el plástico de un vidrio, y cuya viscosidad suele ser igual a $10^{13,3} \mathrm{dPas}$. Asimismo, la temperatura superior de cristalización de un proceso vitrocerámico, corresponderá con el intervalo térmico donde sea posible la máxima cristalización sin deformación del material. Por lo general, estará en función de la temperatura de líquidus de la fase cristalina mayoritaria.

En el caso del Proceso Petrúrgico (Fig. 2) se obtienen materiales vitrocristalinos según ciclos térmicos similares a los procesos naturales de formación mineral; es decir, a partir de la nucleación y cristalización de un fundido desde su temperatura de líquidus y durante su enfriamiento hasta temperatura ambiente (cristalización primaria de un fundido).

En este proceso, es necesario un riguroso control de la composición química inicial, la cual debe favorecer la obtención de fundidos en los que puedan cristalizar fases con facilidad de sustituciones isomorfas, ya que la desvitrificación va a depender de la capacidad de los constituyentes para organizarse entre sí para formar estructuras cristalinas estables. Para estimar la evolución de los procesos de desvitrificación por vía petrúrgica, existen diferentes métodos que permiten evaluar, mediante el cálculo de parámetros
The mechanisms for producing the nucleation of a glass can be homogeneous, when the own glassy matrix crystallizes or heterogeneous if the nucleation is developed from particles with different chemistry composition or from the interfaces determined by the surfaces that limit to the melted glass.

Irom the kinetic point of view, the nucleation and crystallization rates show each maximum development intervals with respect the temperature, (Fig. 1). The nucleation rate depends, in addition to the probability on formation of stable nucleus, on the diffusion of the different constituents necessary for the development of the nucleus. Also, the crystalline growth rate is influenced by the difussion capability of the chemical components until the crystal development.

The experimental study of the viscosity variation as compared to the temperature, can be defined a series of intervals delimited by fixed viscosity points that in good measure affects the process of controlled devitrification. In general terms, to obtain an effective nucleation, the optimum temperature must be located within the corresponding thermal interval to a value of the equal viscosity to $10^{11}-10^{12} \mathrm{dPas}$, that is to say, temperatures slightly superior at the vitreous transformation temperature ( $\mathrm{Tg}$ ), the one which represents the boundary between the rigid and the plastic stages and whose viscosity tends to be equal to $10^{13.3}$ dPas. Also, the onset of temperature for the crystallization process, will correspond with the thermal interval where it will be possible the maximum crystallization without deformation of the material. Generally, this will be function of the liquidus temperature of the major crystalline phase.

In the case of the Petrurgical Process (Fig. 2) are obtained glass-ceramics according to similar thermal cycles to the natural processes from mineral genesis., that is to say, the nucleation and crystallization from the melt by direct slow cooling from higher temperatures to ambient temperature (primary crystallization).

In this process, it is necessary a rigorous control of the initial chemical composition, which must favor the obtention of melts in those which could crystallize phases with easy substitutions, since the devitrification depends on the capacity on the constituents to be organized in order to form stable crystalline structures. To estimate the evolution of the process of devitrification by the petrurgical route, there are different methods that allow to evaluate the geochemical parameters of a melt with a given 


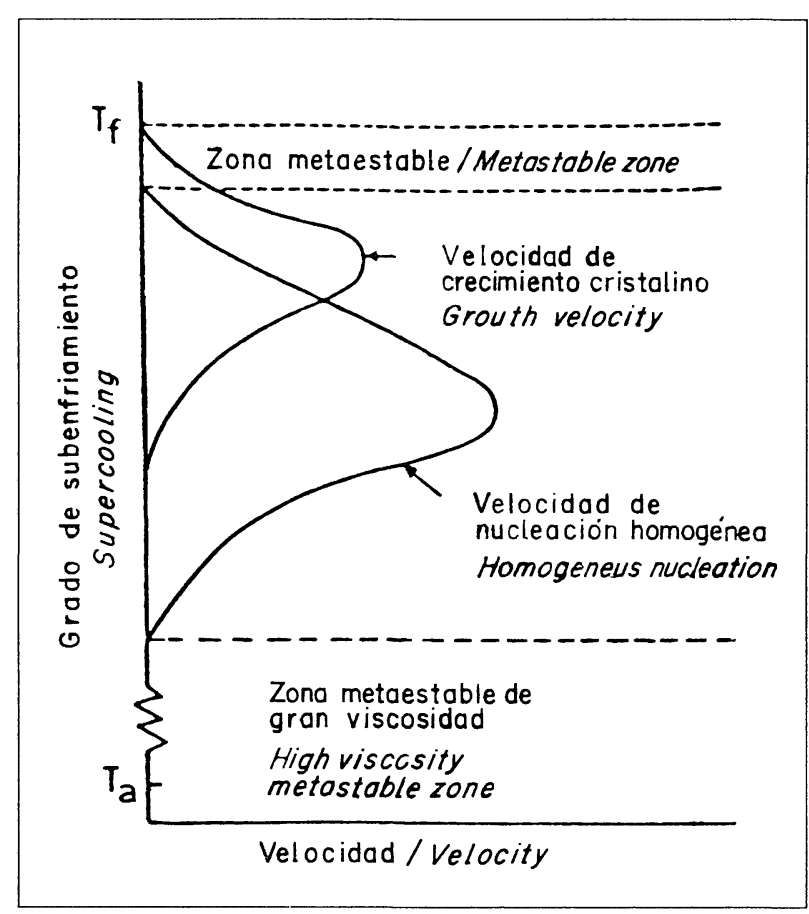

Fig. 1.- Variación de las velocidades de nucleación y crecimiento cristalino en vidrios en función del grado de subenfriamiento.

Fig. 1.- Nucleation and crystalline growth rates in glasses as a function of supercooling.

geoquímicos, el comportamiento de un fundido con una composición determinada. Dichos métodos están basados en adaptaciones de las secuencias teóricas de cristalización conocidos para diferentes sistemas, $(5,6,7)$.

La vía petrúrgica es la más comúnmente aplicada en la fabricación de materiales vitrocerámicos a partir de materias primas naturales (rocas y minerales) y residuos industriales (escorias de fundición, etc...). Suelen ser fundidos silicatados, con bruscos cambios de viscosidad en intervalos de temperatura muy reducidos, lo que determina una fuerte tendencia a la desvitrificación, típica de vidrios aptos para su moldeo por colado. En general, el proceso seguido es: fusión y homogeneización del fundido; colado sobre moldes preforma y ciclos de enfriamiento lento, apropiados para conseguir la desvitrificación de las fases cristalinas mayoritarias.

En el segundo caso se habla de Proceso Vitrocerámico (Fig. 2b) y consiste en provocar la desvitrificación en un vidrio, previamente obtenido mediante tratamientos

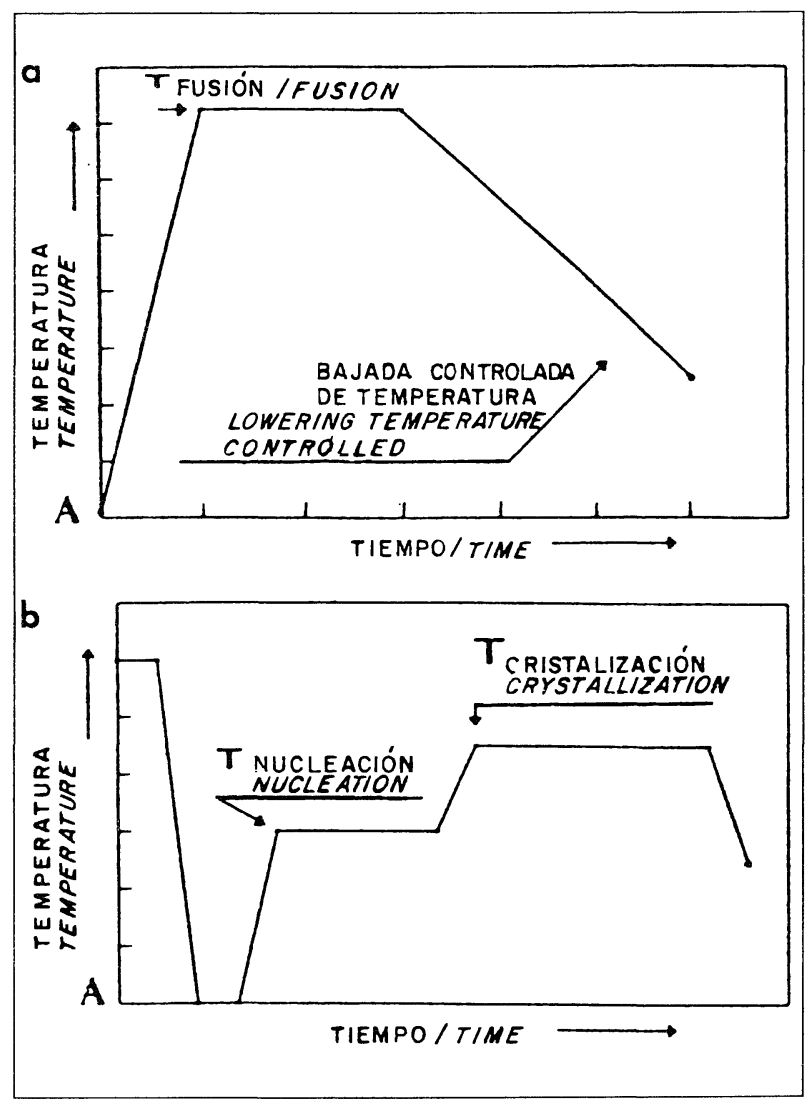

Fig. 2.- Diferentes ciclos térmicos en el proceso de producción de materiales vitrocerámicos: a) P'roceso petrúrgico y b) P'roceso vitrocerámico propiamente dicho.

Fig. 2.- Several thermal cycles on the glass-ceramics production: a) Petrurgical process and b) As such named, glass-ceramic process.

composition. These methods are based on adjustments of the theoretical crystallization sequences known for different systems; in existing relationship between the glass formation elements s and modifiers $(5,6,7)$.

The petrurgical route is the most usual process applied to the glass-ceramics manufacture obtained from natural raw materials (rocks and minerals) and industrial wastes (slags, fly ashes...). They are silicate melts showing very step variation of viscosity being more adequated for moulding by pouring. As a rule. the process is the following : fusion and homogeneization of the molten composition, pouring on moulds, preform and cycles of appropriate slow cooling to obtain the devitrification of the major crystalline phases.

In the second case which is named the Glass-ceramic Process (lig. 2b) consists of promotion the devitrification in a glass previously obtained through 
de nucleación y cristalización controlados (cristalización secundaria de un vidrio).

La vía vitrocerámica es el proceso seguido para la obtención de la mayoría de los materiales vitrocerámicos comercializados fabricados a partir de materias primas, puras o de síntesis. La representación de la formación/no formación de fases cristalinas o núcleos en la matriz cristalina en función de la temperatura y el tiempo de tratamiento, da lugar a las denominadas curvas TTT (TransformaciónTemperatura-Tiempo), las cuales permiten visualizar fácilmente los intervalos de nucleación y crecimiento cristalino (Fig. 3). treatments from nucleation and controlled crystallization ( secondary crystallization from a glass).

The glass-ceramics route is the process followed for obtention of the higher percentaje of the glass-ceramics marketed manufactured from pure or synthesis raw materials. The formation of the crystalline phases is a function of the temperature and the treatment time. giving rise for the designated curves TTT

(Transformation -Temperature - Time) curves, those which permit to visualize easily the intervals of nucleation and crystalline growth (Fig. 3).

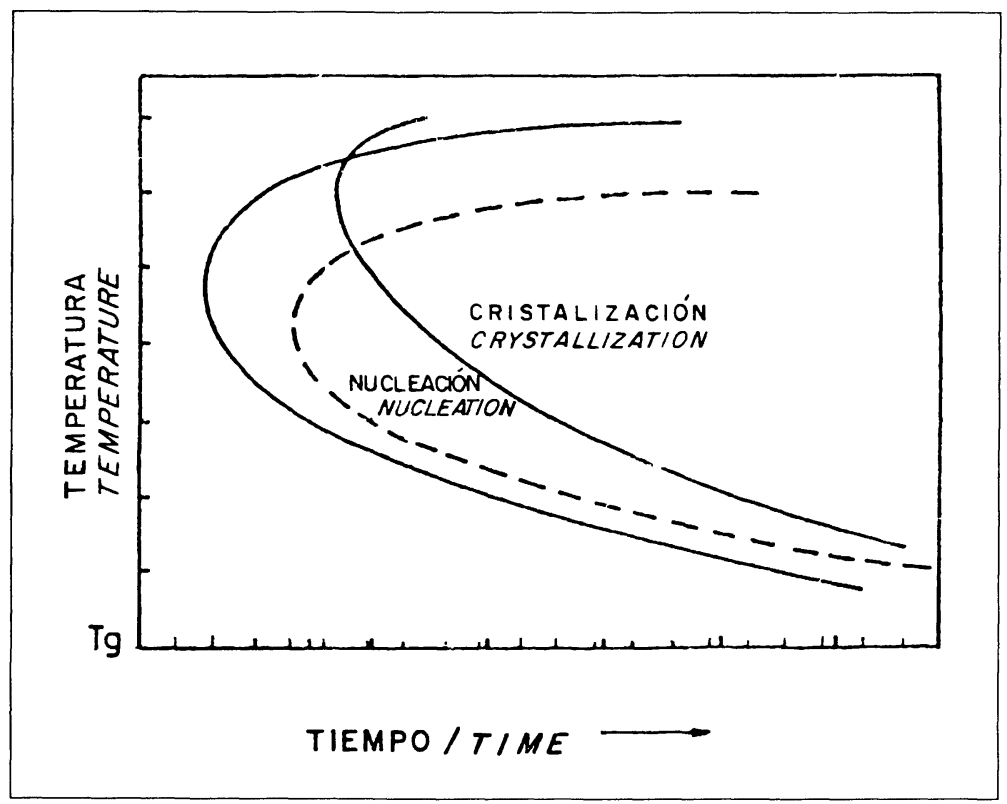

Fig. 3.- Curvas T"I"l (o de transformación - temperatura - tiempo) para la nucleación y cristalización de vidrios

Fig. 3.- TTT (temperature - time - transformation) curves for nucleation and crystallization of glasses.

En ambos procesos (vitrocerámico y petrúrgico) es usual la adición de agentes nucleantes en las composiciones originales para favorecer la nucleación, sobre todo en aquellos sistemas que dan lugar a vidrios muy estables $y$, por tanto, presentan una baja tendencia a la desvitrificación. Aunque su uso es general, en vidrios con una alta tendencia a cristalizar (como los formados a partir de rocas, minerales y residuos industriales), éste se justifica más para el afinado de la microestructura y mejora de las propiedades que para provocar la nucleación (6).

Estos aditivos, crean distintas discontinuidades en la red vítrea actuando como centros de la nucleación. Para que sean realmente eficaces, deben ser sustancias con una velocidad de nucleación elevada y fácilmente
In both processes (glass-ceramic and petrúrgical) is usual the addition of nucleating agents in the original compositions to favor the nucleation, above all in those systems that produces very stable glasses and. by so much, present a decrease to the devitrification. Though their use is in general in glasses with a high trend to crystallize (as the formed from rocks, minerals and industrial residues), this is for improving the microstructure and properties than to promote the nucleation (6).

These additives, produce different discontinuities in the glass network acting as centers of the nucleation. In order to be actually effective, they should be substances with a high rate of nucleation and easily: 
solubles en el vidrio a temperaturas altas. Durante el enfriamiento, la solubilidad de estas sustancias debe disminuir para permitir la segregación y formar gérmenes de núcleos estables.

Pueden clasificarse en dos grandes grupos: uno en el que se incluyen óxidos tales como el $\mathrm{TiO}_{2}, \mathrm{ZrO}_{2}$, $\mathrm{P}_{2} \mathrm{O}_{5}, \mathrm{~V}_{2} \mathrm{O}_{5}, \mathrm{Cr}_{2} \mathrm{O}_{3}, \ldots$ y haluros, fosfatos, etc..., que actúan por diferentes mecanismos (cambio de valencia, descompensadores de carga,...) segregándose de la matriz vítrea y favoreciendo la formación de núcleos. Este tipo de nucleantes suelen incorporarse en proporciones entre el $1 \%$ y el $10 \%$. El segundo grupo, menos soluble, lo integran algunos sulfuros y ciertos metales en forma elemental como el $\mathrm{Pt}, \mathrm{Ag}, \mathrm{Cu}$ y $\mathrm{Au}$. La menor solubilidad de estos agentes nucleantes, suele resolverse aplicando procesos de fotosensibilización (desvitrificación controlada fotoestimulada), ampliamente utilizados en la cristalización de vidrios utilizados en la cristalización de vidrios pertenecientes al sistema $\mathrm{Li}_{2} \mathrm{O}-\mathrm{Al}_{2} \mathrm{O}_{3}-\mathrm{SiO}_{2}(1,4)$.

\section{TIPOS DE MATERIALES VITROCERÁMICOS EN FUNCIÓN DE SUS MATERIAS PRIMAS Y APLICACIONES}

Según la naturaleza de las materias primas utilizadas en la fabricación de vitrocerámicos, éstos pueden clasificarse como $(8,9)$ :

a) Vitrocerámicos técnicos. Son generalmente blancos y se obtienen a partir de materias primas utilizadas en la fabricación de la mayoría de vidrios comerciales. Se agrupan según el componente mayoritario: $\mathrm{Li}, \mathrm{Mg}, \mathrm{B}$, $\mathrm{Ba}$, etc...Es frecuente la adición de otros óxidos con el fin de variar las propiedades del material.

b) Vitrocerámicos para usos arquitectónico o industrial del tipo de materiales petrúrgicos. Cuya materia prima está constituida por rocas, minerales y mezclas de ambos y que pueden obtenerse incluso por procesos de sinterización.

c) Vitrocerámicos de usos arquitectónicos a partir de residuos industriales. Fabricados a partir de escorias y desechos de origen metalúrgico, o bien fabricados a partir de las cenizas de combustión de sólidos y residuos industriales.

a) Materiales Vitrocerámicos de uso técnico o doméstico obtenidos a partir de materias primas puras.

Los materiales vitrocerámicos obtenidos a partir de materias primas puras, (de síntesis o técnicos (8) y (9)), constituyen la mayoría de los vitrocerámicos comerciales. soluble in a glass at high temperatures. During the cooling, the solubility of these substances must be reduced to allow the segregation and to form germes of stable nuclei.

They can be classified in two groups: one which include oxides as $\mathrm{TiO}_{2}, \mathrm{ZrO}_{2}, \mathrm{P}_{2} \mathrm{O}_{5}, \mathrm{~V}_{2} \mathrm{O}_{5}, \mathrm{Cr}_{2} \mathrm{O}_{3}, \ldots$ and halides, phosphates, etc..., that act by different mechanisms (valency change, charge decompensation...) being segregated of the vitreous matrix and favouring the nuclei formation. This type of nucleating agents tend to be incorporated in proportions between $1 \%$ and 10\%. The second group, less soluble, are integrated by some sulphurs and certain metals in elemental form as the Pt, $\mathrm{Ag}, \mathrm{Cu}$ and $\mathrm{Au}$. The smaller solubility of these nucleating agents, tends to be solved by applying processes of photosensitivity (devitrification controlled by photoestimulation). widely used in the glasses crystallization used in the $\mathrm{Li}_{2} \mathrm{O}-\mathrm{Al}_{2} \mathrm{O}_{3}-\mathrm{SiO}_{2}$ system $(1,4)$.

\section{TYPES OF GLASS - CERAMICS AS A FUNCTION OF THEIR RAW MATERIALS AND APPLICATIONS}

According to the nature of the raw materials used in the manufacture of glass-ceramics, these can be classified as (8,9):

a) Technical glass-ceramics. They are generally white and are obtained as from raw materials used in the manufacture of most of commercial glasses. They are grouped according to the major components: $\mathrm{Li}, \mathrm{Mg}$, $B, B a$, etc...It is frequent the addition of other oxides in order to vary the final properties of these products.

\section{b) Glass-ceramics for architectural or industrial uses} of the petrurgical type. Whose raw materials are constituted by rocks, mineral and mixtures of both. They can be produced also by sinter nucleation and crystallization.

c) Glass-ceramics for architectural use obtained from industrial wastes. They are manufactured from slags, red muds, ashes... of metallurgical or thermal power station origin, or well manufactured from ashes of combustion of solids and industrial residues.

\section{a) Glass-ceramics of domestic or technical use} obtained from pure raw materials.

(ilass-ceramics obtained from pure raw materials ( synthesis or technical (8) and (9)), constitute most of the commercial glass-ceramics. 
Desde que en 1957 se llevara a cabo la primera patente de material vitrocerámico por Corning Glass, se han realizado numerosos trabajos de investigación sobre estos materiales por sus buenas aplicaciones tecnológicas, fundamentalmente en los años sesenta y setenta. La mayor parte de los vitrocerámicos comerciales existentes, se consiguen a partir de vidrios de silicatos con $\mathrm{Li}_{2} \mathrm{O}$, debido a la elevada intensidad de campo del $\mathrm{Li}^{+}$, que favorece la cristalización, (10-15).

Estos vitrocerámicos tienen buenas propiedades mecánicas y eléctricas. Cuando se utilizan $\mathrm{TiO}_{2} \circ \mathrm{P}_{2} \mathrm{O}_{5}$ como catalizadores de la nucleación se obtienen materiales con muy bajos coeficientes de dilatación térmica. El mismo comportamiento se ha observado en el sistema $\mathrm{Li}_{2} \mathrm{O}-\mathrm{ZnO}-\mathrm{SiO}_{2}$, en el que se obtienen materiales vitrocerámicos con altas prestaciones mecánicas. Otros sistemas estudiados, de los que también se han obtenido materiales vitrocerámicos con buenas propiedades, han sido los sistemas: $\mathrm{Li}_{2} \mathrm{O}-\mathrm{CdO}-\mathrm{SiO}_{2}, \mathrm{Li}_{2} \mathrm{O}-\mathrm{MgO}-\mathrm{Al}_{2} \mathrm{O}_{3}-\mathrm{SiO}_{2}$ y $\mathrm{Li}_{2} \mathrm{O}-\mathrm{Al}_{2} \mathrm{O}_{3}-\mathrm{SiO}_{2}-\mathrm{TiO}_{2}(16-18)$.

También son importantes los vitrocerámicos obtenidos a partir del sistema $\mathrm{MgO}-\mathrm{Al}_{2} \mathrm{O}_{3}-\mathrm{SiO}_{2}$, ya que son materiales que combinan sus buenas propiedades dieléctricas con su alta resistencia mecánica y sus valores medios y bajos de coeficientes de dilatación térmica. Dichas propiedades se deben a la formación de cordierita en un amplio rango de temperaturas. La marca registrada Neoparis constituye un interesante material vitrocerámico sinterizado cuyo uso está muy extendido en aplicaciones arquitectónicas en Japón, tal y como se muestra en la Figura 4. El proceso de obtención de este material consiste en la sinterización (sin presión) de partículas vítreas que, por reblandecimiento a unos $850^{\circ} \mathrm{C}$, se unen, para, posteriormente, en una cocción a unos $950^{\circ} \mathrm{C}$, nuclear la cristalización en los "bordes de grano" ficticios de las partículas vítreas originales. Con un tratamiento posterior de cristalización, a $1.100^{\circ} \mathrm{C}$, se completa la cristalización del material, que finalmente presenta un aspecto semejante a una piedra, roca natural o incluso de un gres porcelánico ( Figura 5 ). Las ventajas de este material vitrocerámico en la construcción es que presenta mejores propiedades mecánicas y de resistencia a la abrasión que el gres porcelánico y que puede ser moldeado en caliente en función de su lugar de colocación, debido a la existencia de un alto porcentaje de vidrio residual ( Figura 6 ) (19).

b) Materiales vitrocerámicos de uso arquitectónico a partir de materias primas naturales.

Globalmente, se consideran como tales aquellos materiales obtenidos a partir de escorias, rocas y minerales. La terminología más usada para designar a estos materiales es la de "materiales petrúrgicos" (o sitals), si bien no es del todo correcta, pues el adjetivo
Since in 1957 was carried out the first patent on glassceramics by Corning Glass, they have been accomplished numerous investigation projects on these materials and their technological applications, basically in the sixties and seventies. The higher commercial existing, are procured from glasses in the $\mathrm{Li}_{2} \mathrm{O}$ compositions, due to the $\mathrm{Li}{ }^{+}$high ionic field intensity, that favors the crystallization, (10).

These glass-ceramics depict good mechanical and electrical properties. When $\mathrm{TiO}_{2}$ and $\mathrm{P}_{2} \mathrm{O}_{5}$ are used as catalysts of the nucleation they are obtained materials with very low thermal expansion coefficients. The same behavior, it has been observed in the system $\mathrm{Li}_{2} \mathrm{O}-\mathrm{ZnO}-\mathrm{SiO}_{2}$, where are obtained glass-ceramics with high mechanical performance. Other studied systems which also they have been obtained with good properties, have been the $\mathrm{Li}_{2} \mathrm{O}-\mathrm{CdO}-\mathrm{SiO}_{2}, \mathrm{Li}_{2} \mathrm{O}-\mathrm{MgO}-\mathrm{Al}_{2} \mathrm{O}_{3}-\mathrm{SiO}_{2}$ and $\mathrm{Li}_{2} \mathrm{O}-\mathrm{Al}_{2} \mathrm{O}_{3}-\mathrm{SiO}_{2}-\mathrm{TiO}_{2}(16-18)$.

Also they are important glass-ceramics obtained from the $\mathrm{MgO}-\mathrm{Al}_{2} \mathrm{O}_{3}-\mathrm{SiO}_{2}$ system, since they are materials that combine their good dielectric properties with their high mechanical strength and their average values of thermal expansion coefficients. Such properties should be due to the formation of cordierite in a wide temperature range. The trademark Neoparis is a very interesting sintered glass-ceramic which is widely used in Japan in architectural applications, as is shown in the Figure 4. The obtention process is a sintering (pressureless) of glassy particles which after softening at $850^{\circ} \mathrm{C}$ are joined in order to nucleate the crystallization from the fictive "grain boundaries" in a heating at $950^{\circ} \mathrm{C}$ of the original grains. Afterwards, a heat treating at $1.100^{\circ} \mathrm{C}$ (Figure 5) completes the crystallization process. which finally takes the appearance of a natural stone or porcelaine stoneware. The main characteristic of this glass-ceramic for building is its capability for being moulded by heating at high temperatures due to the residual glassy phase (Figure 6) (19).

\section{b) Glass-ceramics for architectural use obtained from natural raw materials.}

Basically, such materials are considered when are obtained from slags, rocks and minerals. The most used terminology to designate these materials is "petrurgical materials" or sitals, even though it is not of the all correct since the adjective "petrurgical" 
"petrúrgico" indica un tipo de procesado y no un determinado tipo de materia prima.

En (5) y (7) se hace una revisión histórica exhaustiva de la evolución y desarrollo que han experimentado los materiales vitrocerámicos desde los primeros intentos encaminados a la obtención de materiales vitrocristalinos a partir de una mezcla de materias primas naturales y, más concretamente, a partir de composiciones basálticas.

Tradicionalmente, es en los países del Este de Europa donde la industria petrúrgica tiene sólidas bases con numerosas instalaciones para la fabricación de productos en Rusia, Bulgaria, Polonia, República Checa, Alemania (sobre todo en la anterior República Democrática Alemana). Más recientemente, se pueden incluir en esta lista a países como: el Reino Unido, Italia, Austria, EE.UU y Japón. La Fig. 7 muestra un aspecto de materiales vitrocerámicos de tipo petrúrgico ( basaltic ) que se fabrican en la República Checa por la firma EUTIT.

Como ejemplo de materiales vitrocerámicos a partir de sustancias puras obtenidas por vía petrúrgica, son destacables las investigaciones llevadas a cabo en el Dpto. de Materials Science del Imperial College de Londres las cuales han dado lugar a distintas patentes (20), así como las realizadas por J. M ${ }^{\text {a }}$. Rincón en el CSIC en los últimos años. El material obtenido, llamado SILCERAM, es el resultado de la cristalización controlada de un vidrio formulado en el sistema CaO-MgO- $\mathrm{Al}_{2} \mathrm{O}_{3}-\mathrm{SiO}_{2}$. En (24-26) se exponen las características de este material. El intervalo de composiciones que estos autores han utilizado es: $\mathrm{CaO}=$ $0-30 \% ; \mathrm{MgO}=0-30 \% ; \mathrm{Al}_{2} \mathrm{O}_{3}=5-35 \%$ y $\mathrm{SiO}_{2}=35-75 \%$. Para provocar la cristalización se añaden, como agentes nucleantes, $\mathrm{Cr}_{2} \mathrm{O}_{3}$ y $\mathrm{Fe}_{2} \mathrm{O}_{3}$ en cantidades del 0,5 al $10 \%$. La adición de estos óxidos hace posible la cristalización primaria, ya que ambos actúan conjuntamente estimulando la nucleación y crecimiento de pequeños cristales de espinelas. Asimismo, otros factores esenciales, de cuyo control depende la consecución de buenos materiales vitrocristalinos, son la temperatura y el tiempo de los tratamientos térmicos realizados. Así, cuanto mayor es la capacidad de cristalización del vidrio y menor velocidad de crecimiento de los cristales, más fina es la microestructura del producto final. En caso contrario, la microestructura se caracteriza por poseer un menor número de cristales, pero de mayor tamaño.

Una roca puede tener ocho o nueve minerales normativos pero, después de la fusión y de la recristalización, no suelen aparecer más que tres o cuatro fases, fundamentalmente: magnetita, un piroxeno de tipo means a form of processing and not a given type of raw material.

In (5) and (7), is given an exhaustive historical review of the evolution and development that they have experimented the glass-ceramics from the first attempts for their obtention from natural raw materials and more specifically from basaltic compositions.

Traditionally, the countries of the East Europe have solid bases with numerous facilities for the products manufacture in Russia, Bulgaria, Poland, Czcheck Republic, (above all in the formert German Democratic Republic). Most recently, it has be included in this list countries as the United Kingdom, Italy, Osterreich, EE.UU and Japan.The Figure 7 shows an aspect of petrurgical glass-ceramic (basaltic) manufactured in the Czcheck Republic ( EUTIT Company)

As an example of glass-ceramics processed from pure substances and by petrurgical route they are notable investigations carried out in the Dept. of Material Sciences of the Imperial College of London which has developped several patents (20), as well as the accomplished by J. $M^{a}$. Rincón in the last years. The obtained material, named SILCERAM, it is the result of the controlled crystallization of a glass formulated in the system $\mathrm{CaO}-\mathrm{MgO}-\mathrm{Al}_{2} \mathrm{O}_{3}-\mathrm{SiO}_{2}$. The references (24-26) show the main characteristics of this material. The composition interval that these authors have used are: $\left(\mathrm{aO} \cdots 0-30 \% ; \mathrm{MgO}=0-30 \%, \mathrm{Al}_{2} \mathrm{O}_{3}-5-35 \%\right.$ and $\mathrm{SiO}_{2}=35-75 \%$. To promote the crystallization, are added as nucleating agents: $\mathrm{Cr}_{2} \mathrm{O}_{3}$ and $\mathrm{Fe}_{2} \mathrm{O}_{3}$ in 0.5 to the $10 \%$ weight percentajes. The addition of these oxides makes possible the primary crystallization, since both act jointly stimulating the nucleation and growth of small crystals of spinels.

Likewise, other factors are essential for the attainment of good glass-ceramics materials as the temperature and time of the thermal treatments. Thus, as much greater is the crystallization capacity of the glass, smaller is the growth rate of crystals, finer the microstructure of the final product. On the other hand, the microstructure is characterized by containing a smaller number of crystals, but of greater size.

A rock is composed usually by eight or nine of these normative minerals but, after the fusion and recrystallization, it appears only three or four phases. basically: magnetite, pyroxene of diopside type, 


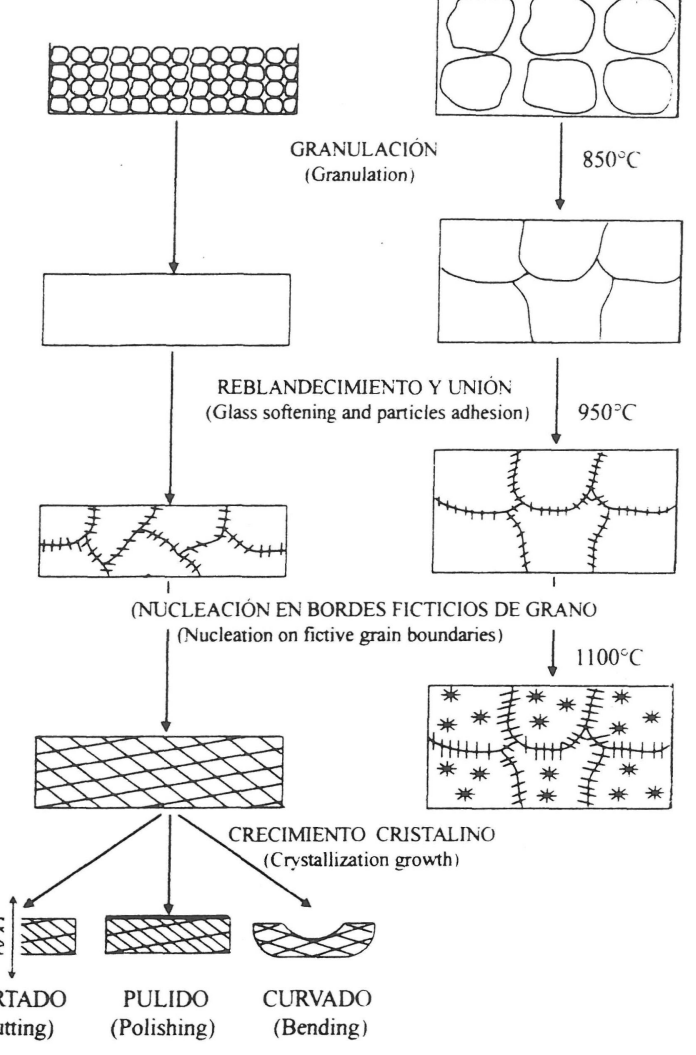

Fig. 5.-Diagrama esquemático del proceso defabricación del vitrocerámico de uso arquitectónico Neoparis, mostrando la evolución microestructural.

Fig. 5.-Flux diagramme of procesing of Neoparis glass-ceramic, showing the microstructure evolution.

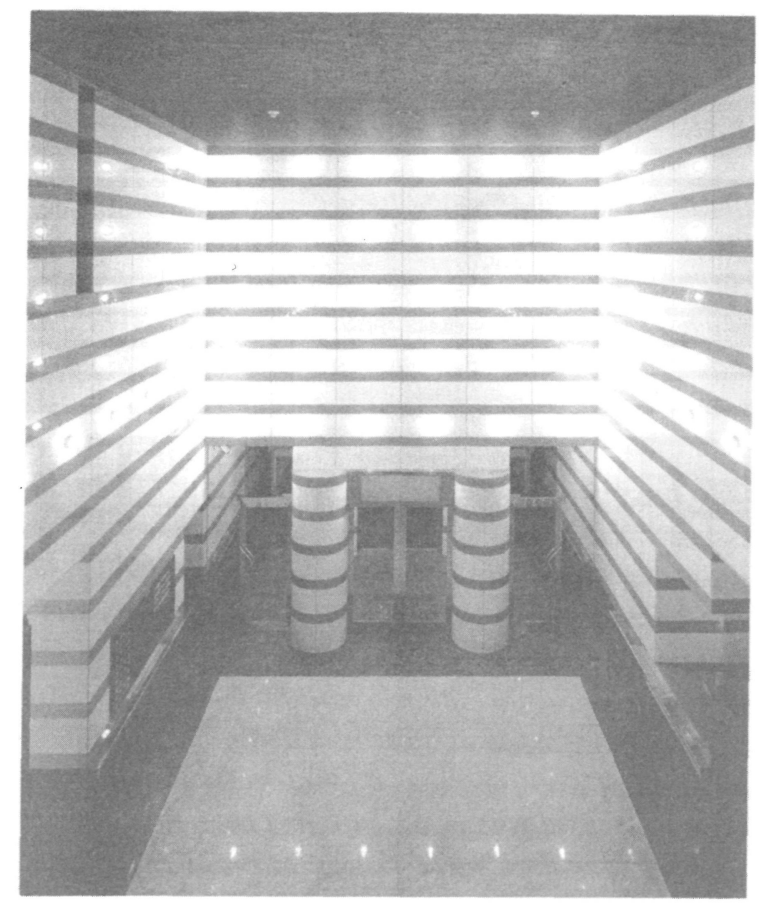

Fig. 6.- Un ejemplo real de aplicación arquitectónica del vitrocerámico Neoparis en Tokio.

Fig. 6.-An example in Tokio of architectonic application of the Neoparis.

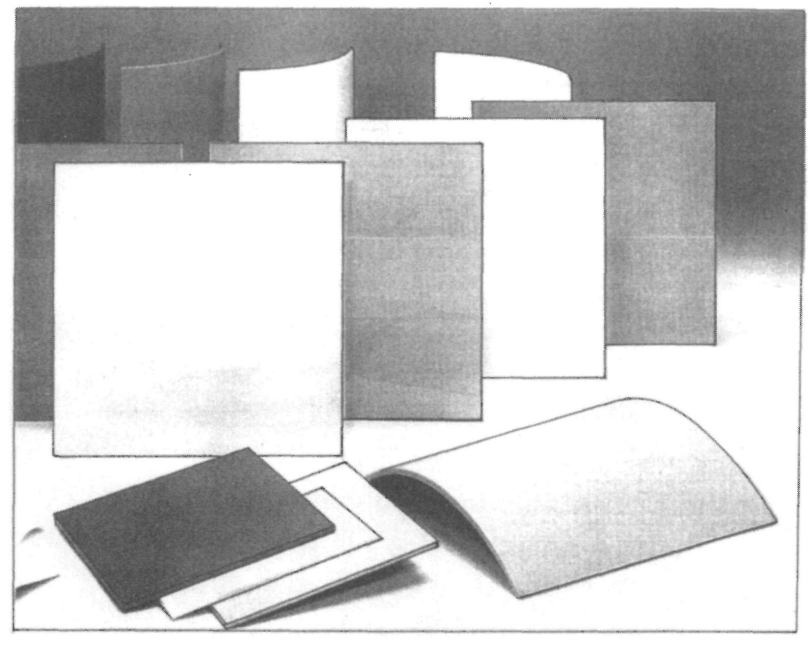

Fig. 4.- Varias plaquetas planas y curvadas del vitrocerámico japonés de uso arquitectónico Neoparis.

Fig. 4.- Several samples of plane and curved tiles of the japanese glassceramic Neoparis.

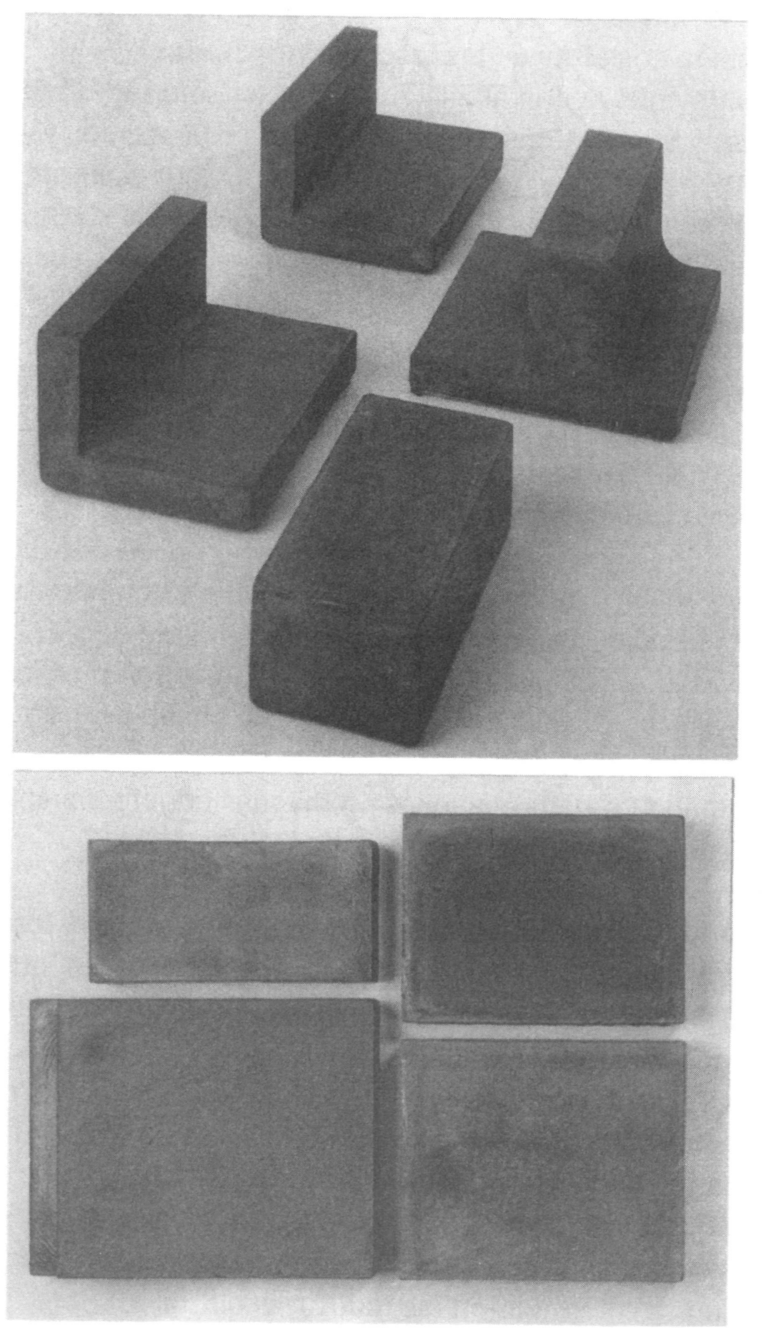

Fig. 7.- Varias plaquetas y piezas del vitrocerámico de tipo petrúrgico Basaltic, de la firma Eutit.

Fig. 7.- Several tiles from the Basaltic, Eutit petrurgical glass-ceramic. 
diópsido, a veces plagioclasa (labradorita-anortita) y, más raramente, olivino. Los puntos de fusión estipulados para estos minerales varían desde los $1.118^{\circ} \mathrm{C}$ de la albita hasta los $1.686^{\circ} \mathrm{C}$ de la leucita. La mayoría sobrepasan los $1.500^{\circ} \mathrm{C}$. Naturalmente, la fusión de sus mezclas disminuyen las temperaturas de fusión de la roca $\left(1.100^{\circ} \mathrm{C}-1.300^{\circ} \mathrm{C}\right)$.

$\mathrm{El}$ orden de aparición y desarrollo de estas fases, por debajo de los $1.300^{\circ} \mathrm{C}$, depende de los tratamientos térmicos aplicados: $1^{\circ}$ ) Si éstos son incluidos en el curso de un enfriamiento lento del fundido original desde la temperatura de líquidus (6). $2^{\circ}$ ) Si por el contrario, una vez obtenido el vidrio se aplican tratamientos térmicos desde bajas temperaturas cercanas a los $500^{\circ} \mathrm{C}$, se provoca una desvitrificación o recristalización secundaria en el vidrio de partida (23).

El amplio intervalo de temperaturas y las dificultades propias del procesado, hacen difícil conseguir piezas homogéneas en todos sus puntos en cuanto al tipo y tamaño cristalino de las fases desvitrificadas. Igualmente, la cristalización, puede ser sólo superficial o afectar a la totalidad de la masa vítrea considerada (24). La homogeneidad de las microestructuras de materiales vitrocerámicos, obtenidos con materias primas naturales, sigue siendo un problema incluso en las actuales plantas de producción de tecnologías avanzadas. Aún así, los materiales vitrocerámicos, obtenidos a partir de rocas basálticas, se caracterizan por su gran inercia química, baja velocidad de lixiviado y buena conductividad eléctrica, alta resistencia a la abrasión y buena resistencia mecánica (4).

Para obtener piezas de geometría estable y con buenas propiedades, las temperaturas de tratamiento deben de ser inferiores a la temperatura de deformación plástica. La adición de nucleantes hace que, en buena medida, se consigan productos con microestructuras muy finas, evitando las deformaciones producidas por crecimientos cristalinos (25-26).

Por las buenas propiedades que pueden obtenerse, los materiales vitrocerámicos de rocas basálticas presentan multitud de aplicaciones industriales, constituyendo una valiosa alternativa a materiales y metales tradicionales. En pavimentos industriales y en hidrociclones, presentan una aplicación directa por sus condiciones favorables. También, los tubos de vitrocerámicos de basalto son óptimos para la protección de tuberías de hierro, por su resistencia al desgaste por abrasión en conducciones de líquidos corrosivos en las industrias químicas. Son, también, muy buenos materiales como matrices para la inmovilización y aislamiento de residuos tóxicos y radioactivos por sus bajas velocidades de lixiviación y estabilidad química a largo plazo (27-28). La Tabla I da una visión de conjunto de las propiedades de los sometimes plagioclase (abradorite-anorthite) and, more rarely, olivine. The melting points for these minerals vary from $1.118^{\circ} \mathrm{C}$ for the albite to $1.686^{\circ} \mathrm{C}$ of leucite. The majority surpass $1.500^{\circ} \mathrm{C}$. Naturally, the fusion of their mixtures reduce the melting temperatures of the rock $\left(1.100^{\circ} \mathrm{C}-1.300^{\circ} \mathrm{C}\right)$.

The development sequence of these phases, below $1300^{\circ} \mathrm{C}$, depends on the applied thermal treatments ${ }^{\text {st }}$ ) If these are included in the course of a slow cooling of the original melt from the liquidus temperature (6). $2^{\text {nd }}$ ) On the contrary, once obtained the glass, is applied thermal treatments from lower temperature, approx $=500^{\circ} \mathrm{C}$ promoting the secondary devitrification or recrystallization in the original glass (23).

The wide temperatures range and the own difficulties of the process, makes difficult to obtain homogeneous samples in all their areas with respect to type and crystalline size of the devitrified phases. Similarly, the crystallization can be only surface crystallization or to affect the whole considered glassy matrix (24). The homogeneity of the microstructure of glass-ceramics obtained with natural raw materials, continues being a problem even in the current plants of advanced production technologies. Even so, these materials obtained from basaltic rocks are characterized by their high chemical inertia, low speed of leaching and electrical conductivity and high mechanical and abrasion resistance (4)

To obtain stable geometry pieces and with good properties, the treatment temperatures should be inferior to the plastic deformation temperature. The addition of nucleating agents causes that, in good measure, are produced materials with very fine microstructures avoiding deformations produced by crystalline growth (25-26).

Due to the good properties which can be obtained, the glass-ceramics obtained from basaltic rocks depict a lot of industrial applications, constituting a valuable alternative to other materials and traditional metals (21). In industrial pavements and in hydrociclons, they show a direct application by their favorable conditions. Also, the glass-ceramics pipes of basalts are optimum for the protection of iron pipelines by their wear resistance by abrasion in corrosive liquids in the chemistry industries. They are, also, very good material as matrix for the immobilization and/or isolation of toxic and radioactive residues. Their low leaching rates and chemical stability in long term (27-28). The Table I shows a panorama of the general properties of glass-ceramics for architectural 
TABLA I (TABLE I)

Propiedades físicas y tecnológicas de materiales vitrocerámicos para la construcción y de otros materiales similares Physic and technological properties of building glass-ceramics compared to other similar materials

\begin{tabular}{|c|c|c|c|c|c|c|c|}
\hline & \multicolumn{2}{|c|}{$\begin{array}{l}\text { Vitrocerámico } \\
\text { Glass-ceramic }\end{array}$} & \multirow{2}{*}{$\begin{array}{l}\text { Gres porcelánico } \\
\text { Porcelaine stoneware }\end{array}$} & \multicolumn{3}{|c|}{$\begin{array}{l}\text { Piedras naturales } \\
\text { Natural stores }\end{array}$} & \multirow{2}{*}{$\begin{array}{l}\text { Vidrios } \\
\text { Glasses }\end{array}$} \\
\hline & $\begin{array}{l}\text { Convencional } \\
\text { Conventional }\end{array}$ & Neoparis & & $\begin{array}{c}\text { Basalto } \\
\text { Basalt }\end{array}$ & $\begin{array}{l}\text { Granito } \\
\text { Granite }\end{array}$ & $\begin{array}{l}\text { Mármol } \\
\text { Marbre }\end{array}$ & \\
\hline Densidad $\left(\mathrm{g} / \mathrm{cm}^{3}\right) /$ Density $\left(\mathrm{g} / \mathrm{cm}^{3}\right)$ & $2,4-3,6$ & 2,7 & 2,5 & 2,9 & 2,6 & $2-7$ & 2,4 \\
\hline \multicolumn{8}{|l|}{ Resistencia mecánica/Mechanical strength } \\
\hline $\begin{array}{l}\text { Flexión (MPa)/Flexion (Mpa) } \\
\text { Compresión (MPa)/Compression (MPa) } \\
\text { Módulo de elasticidad (MPa)/ } \\
\text { Elasticity modulus (MPa) }\end{array}$ & $\begin{array}{c}80-300 \\
--- \\
70-180\end{array}$ & $\begin{array}{c}51 \\
12-56 \\
52\end{array}$ & $\begin{array}{c}>50 \\
--- \\
--\end{array}$ & $\begin{array}{c}300 \\
-- \\
100\end{array}$ & $\begin{array}{c}15 \\
6-30 \\
43-61\end{array}$ & $\begin{array}{c}17 \\
9-23 \\
28-84\end{array}$ & $\begin{array}{c}56-70 \\
--- \\
70\end{array}$ \\
\hline \multicolumn{8}{|l|}{ Dureza/Hardness } \\
\hline $\begin{array}{l}\text { Mohs } \\
\text { Vickers }\left(\mathrm{Mn} / \mathrm{m}^{2}\right) \\
\text { Res. Abrasión (Método PEI)/ } \\
\text { Abrasion res. (PEI) } \\
\text { Tenacidad } \mathrm{K}_{\mathrm{IC}}\left(\mathrm{MPam}^{1: 2}\right) / \\
\text { Toughness, } K_{1 \mathrm{C}}\left(\mathrm{MPam}^{1 / 2}\right)\end{array}$ & $\begin{array}{c}8 \\
5.000-8.000 \\
\text { IV } \\
1,5-3,0\end{array}$ & $\begin{array}{l}>5 \\
\cdots \\
\vee- \\
1,8\end{array}$ & $\begin{array}{l}>5 \\
\cdots \\
\cdots \\
1,5\end{array}$ & $\begin{array}{c}7 \\
--- \\
\text { IV }\end{array}$ & $\begin{array}{c}5,5 \\
-- \\
\text { III } \\
1,1\end{array}$ & $\begin{array}{c}3-5 \\
-- \\
111 \\
0,5\end{array}$ & $\begin{array}{l}5 \\
4.000 \\
11 \\
0,6\end{array}$ \\
\hline \multicolumn{8}{|l|}{ Propiedades térmica/Termal properties } \\
\hline $\begin{array}{l}\text { Calor especifico }\left(\mathrm{cal} /{ }^{\circ} \mathrm{C}\right) / \\
\text { Specific heat }\left(\mathrm{cal} /{ }^{\circ} \mathrm{C}\right) \\
\text { Coef. de dilatación lineal }\left({ }^{\circ} \mathrm{C} \times 10^{-6}\right) / \\
\text { Thermal expansion }\left({ }^{\circ} \mathrm{C} \times 10^{-6}\right)\end{array}$ & $\begin{array}{c}\cdots \\
-1,5-+12,0\end{array}$ & $\begin{array}{l}0,19 \\
6,2\end{array}$ & 7 & -- & $\begin{array}{l}0,19 \\
5-15\end{array}$ & $\begin{array}{l}0,19 \\
8-26\end{array}$ & $7-9$ \\
\hline $\begin{array}{l}\text { Resistencia a la helada*/ } \\
\text { Frost resistance }{ }^{*}\end{array}$ & $0,09-3,35$ & 0,028 & $\begin{array}{l}\text { Sin defectos } \\
\text { without defects }\end{array}$ & --- & 0,25 & 0,23 & --- \\
\hline $\begin{array}{l}\text { Absorción de agua }(\%) / \\
\text { Water absorption }(\%)\end{array}$ & $1-5$ & $<1$ & $<1$ & --- & --- & $>1$ & --- \\
\hline
\end{tabular}

*Pérdida de peso después de 25 ciclos desde $25^{\circ} \mathrm{C}$ hasta $-20^{\circ} \mathrm{C}$ en piezas de $15 \times 15 \times 10 \mathrm{~cm}$. (Loss of weight after $25 \mathrm{cycles}$ from $25^{\circ} \mathrm{C}$ until $-20^{\circ} \mathrm{C}$ in pieces of $15 \times 15 \times 10 \mathrm{~cm}$. ) 
materiales vitrocerámicos para usos arquitectónicos comparadas con otros materiales de construcción de usos similares.

c) Materiales vitrocerámicos de uso arquitectónico a partir de residuos industriales.

En la actualidad, se están desarrollando metodologías que permitan aplicar el proceso vitrocerámico, bien por vía petrúrgica bien por vía vitrocerámica, para el reciclado de residuos minerales, escorias y desechos industriales, mezclados o no con otras materias primas naturales o sintéticas, y obtener nuevos materiales que tengan utilidad en la industria o en el sector de la construcción (29-30).

En España, los estudios en este campo son relativamente recientes, destacando los trabajos sobre el aprovechamiento de materias primas naturales o residuos industriales que se han realizado en las últimas décadas por distintos organismos y centros de investigación, Universidades de Barcelona (31-32) y La Laguna (33); Instituto Jaume Almera del CSIC y el Grupo de Investigación en Materiales Vitrocerámicos que dirige Rincón en el Instituto E. Torroja del CSIC, sobre mineralogía aplicada al estudio del proceso cerámico (34-37), caracterización y viabilidad de materias primas naturales en la producción de vitrocerámicos (38- 40); esmaltes cerámicos a base de vidriados basálticos (41); y, además, los más recientes que, sobre la obtención de materiales vitrocerámicos sintéticos, a partir de goethita y de otros residuos de industrias hidrometalúrgicas, se están llevando a cabo dentro de proyectos de investigación, nacionales y europeos (42-44).

Las Figs. 8a y 8b muestran el aspecto de los materiales vitrocerámicos de este tipo obtenidos en nuestros laboratorios. El primero (Fig. 8a), se moldeó en forma de tubo hueco para conocer la capacidad del vidrio de partida para el moldeado de formas con diversos diseños. El segundo (Fig. 8b), fue moldeado en forma de placas, cociéndose en un ciclo de cocción rápida idéntico al utilizado actualmente en la fabricación de pavimentos y revestimientos cerámicos. Las placas resultantes presentan un aspecto similar a pizarras naturales.

\section{CONCLUSIÓN}

El apoyo y fínanciación que empresas del Sector Público y Privado, así como los organismos competentes en materia de Medio Ambiente de la Comunidad Económica Europea están prestando a programas de $\mathrm{I}+\mathrm{D}$ en materiales vitrocerámicos, indican el gran interés del sector empresarial de uses compared with similar materials.

\author{
c) Glass-ceramics of architectural use obtained \\ from industrial residues.
}

Nowadays, new methodologies are being developped that permit to apply the glass-ceramic process, by petrurgical route as well by glass-ceramic route for recycling of mineral wastes, slags, ashes, fly ashes and any other industrial residues, mixed or not with other raw materials, natural or synthetic for obtaining new materials which may have applications in the construction industries (29-30).

In Spain, the studies in this field are relatively recent. emphasizing the projects on the raw materials utilization. natural or industrial residues, that they have been accomplished in the last decades by different organizations and investigation centers, Lniversities of Barcelona (31-32) and La Laguna (33); Institute Jaume Almera, CSIC and the Research Group directed by Rincon from the Institute E. Torroja, CSIC, Madrid on the applied mineralogy to the study of the ceramic process (34-37), characterization and viability of natural raw materialsl in the production of glassceramics (38-40); ceramic enamels based on basaltic glazes (41) and furthermore, the more recent on the materials obtention of synthetic glass-ceramics from goethite, jarosite red muds and other industry residues from the hydrometallurgic industries which are being carrying out within national and European investigation projects (42-44).

The Higs: $8 a$ and $8 b$ show the aspect of glass-ceramics of this type obtained in our laboratories. The first (Fig. 8a) was moulded in the form of hollow pipe to know the capability of the original glass for the moulding with various designs. The second (Fig. 8b) was moulded in the shape of plates being heated in a thermal cycle of identical fast firing to the used currently in the manufacture of pavements and ceramic glazed tiles. The resulting tiles have showed similar aspect to the natural slates stones.

\section{CONCLUSION}

The supporting and finnancing that companies of the public and private sectors, as well as the competent organizations in Environment Policies of the European Economic (ommunity are lending to $R+D$ programs in glass-ceramics show the growing interest on this research and development area of construction 

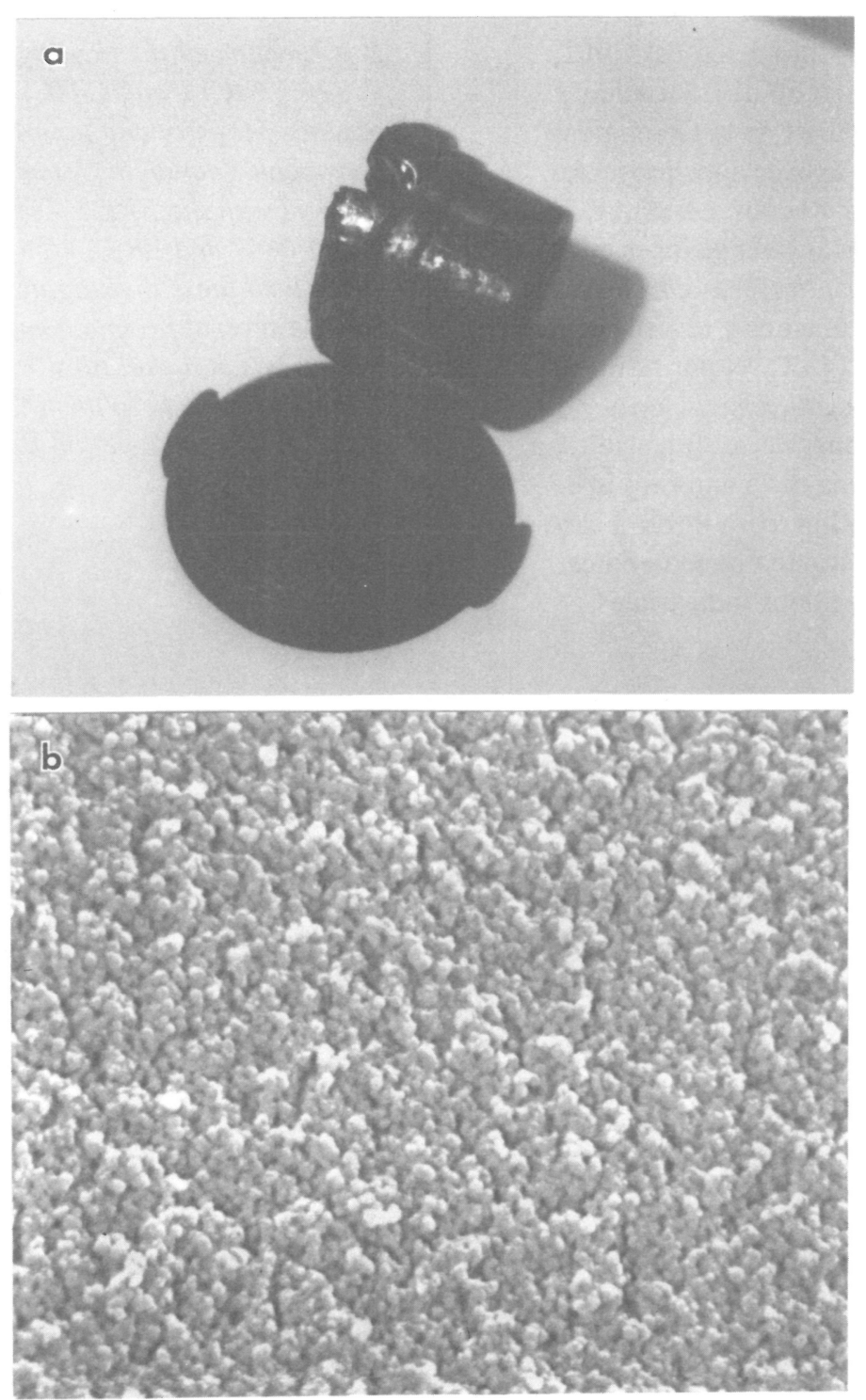

Fig. 8.- a) Una pieza de material vitrocerámico moldeada como un pequeño tubo, obtenida a partir de un residuo industrial (fango rojo); b) microestructura observada por microscopía electrónica de barrido SEM de este tipo de vitrocerámico.

Fig. 8.- a) A sample of glass-ceramic moulded as a small pipe from red mud industrial waste; b) SEM microstructure of this glss-ceramic.

fabricación de materiales de construcción por estos nuevos materiales. Los resultados que en tales proyectos se están consiguiendo, permiten concluir que el proceso vitrocerámico se perfila no sólo como una alternativa real y útil para el reciclado de residuos industriales urbanos y que pueden dar lugar a nuevos materiales como una opción más, e incluso mejorada, para el arquitecto y el constructor de edificios y obras públicas, sino también como un método de obtener productos o materiales de construcción avanzados, con altas características físicas y tecnológicas. materials with respect these new materials. The results that in such projects are being obtaining, will allow to conclude that the glass-ceramic and petrurgical processes are outlined not only as a real and useful alternative for the recycling of urban industrial residues, giving rise to new construction materials as a more option for architecs and the building or construction engineers, but also as methods for obtaining advanced construction materials depicting high physical and technological performances. 


\section{AGRADECIMIENTOS}

Se agradece las ayudas de investigación del CSIC, CICYT y CAICYT del Ministerio de Educación y Ciencia y en especial a la DGXII de la Comunidad Económica Europea por los apoyos a los proyectos BRITE-EURAM: MA2R-CT90 0007 y BRE2-CT94 1018 que han facilitado estas investigaciones en los últimos 25 años, así como a numerosas empresas del sector de fabricación de pavimentos y revestimientos cerámicos del área de CASTELLÓN por su interés y apoyo en el desarrollo de estas investigaciones y que no pueden citarse aquí por razones de confidencialidad. Se agradece, por último, la ayuda de la empresa SALONI de San Juan de Moro, Castellón, para llevar a cabo por primera vez ensayos de fabricación de materiales vitrocerámicos a partir de residuos industriales.

\section{ACKNOWLEDGEMENT}

It is recognized the investigation grants from the C.S.IC., CICYT and CAICYT from the Education and Science Ministry and mainly to the DGXII of the European Economic Community by the continuous support with the BRITE - ELRAM projects $M A 2 R$ CT90-0007 and BRE2-CT94-1018 that they have facilitated these investigations in the 25 last years, as well as several private companies from the ceramic pavements and wall tiles from CASTELLON area. Many thanks also to the SALONI company from San Juan de Moro. C'astellón for its interest and experimental help.

\section{BIBLIOGRAFÍA}

(1) FERNÁNDEZ NAVARRO, J.M.: El Vidrio. Ed. Consejo Superior de Investigaciones Científicas (2 edición), (1991). Madrid.

(2) TAMMAN, G. y HESSE, W.: Die Abhaugigkeit der viskositat vonder temperatur bei unterkühlen flüssig-Keiten. Z. anorg. allog. chem. (1926), 156, 245-256.

(3) STOOKEY, S. D.: History of the development of Pyroceram. Resarch Manag., (1958) 1,155-163.

(4) Mc MILlAN, P.W.: Glass-ceramics. Ed. Academic Press, (2 edición), (1979). New York, London.

(5) GARCÍA VERDUCH, A.: Materiales obtenidos a partir de rocas y escorias fundidas. Jornadas científicas sobre Cerámica y Vidrio Ed. Sección de Ciencia Básica de la Soc. Esp. Ceram. Vidr. y la Universidad de Oviedo (1980), Oviedo.

(6) VICENTE-MINGARRO, I.: Estudio de los Mecanismos de Nucleación y Cristalización en vidrios obtenidos a partir de rocas basálticas. Tesis Doctoral. Ed. U.C.M. (1993). 256 pp.

(7) QUERALT I MITJANS, I.: Dinámica mineral de los procesos de devitrificación en vidrios basalticos. Tesis Doctoral, Fac. de Geología, Universidad de Barcelona (1988).

(8) SCHOLES, S.: Glass-ceramics in USSR. The glass industry, (1974), 55, 14-27.

(9) SCHOLES, S.: Glass-ceramics in USSR. The glass industry, (1975), 56, 99-23.

(10) BEREZHNOI, A. J.: Glass-ceramics and photositalls. Plenum Press, (1970). New York.

(11) WAGSTAFF, FE.: Crystallization and melting kinetics of cristobalite. J. Amer. Cer. Soc., (1969) 52, 650-654.

(12) JACODINE, R.l.: Study of devitrification of lithium glass, J. Amer. Cer. Soc., (1961) 44, 472-475.

(13) WEST, A.R. y GLASSER, F.P.: Crystallization of $\mathrm{Li}_{2} 0-\mathrm{SiO}_{2}$ glasses. En: Advances in nuclei and crystal in glasses. Ed. The glass division of The Amer. Cer. Soc., (1971) Columbus, Ohio.

(14) RINCÓN, J.Ma.: Estudio de nuevos vidrios y materiales vitrocristalinos del sistema $\mathrm{Li}_{2} \mathrm{O}-\mathrm{CdO}-\mathrm{SiO}_{2}$ con posible utilidad en la industria nuclear. Tesis Doctoral. Ed. U.C.M. $n^{\circ}$ 149/84 (1984). Madrid.

(15) RINCÓN, J.Ma.; GONZÁLEZ-OLIVER, C.J.R. y JAMES, P.F.: Phase separation in $\mathrm{Li}_{2} \mathrm{O}_{-} \mathrm{SiO}_{2}$ glases with additions of $\mathrm{V}_{2} \mathrm{O}_{5}, \mathrm{MnO}_{2}$ and $\mathrm{Cr}_{2} \mathrm{O}_{3}$. J. Mat. Sci. (1988) 23, 2512-2516.

(16) ALEIXANDRE, V.; GONZÁLEZ, J.M.; RINCÓN, J.Ma.: Cristalización en algunos vidrios del sistema $\mathrm{Li}_{2} \mathrm{O}-\mathrm{MgO}_{2}-\mathrm{Al}_{2} \mathrm{O}_{3}-\mathrm{SiO}_{2}$ observada, fundamentalmente, por microscopía electrónica Bol. Soc. Esp. Ceram. Vidr. (1971)10, 341-365. 
(17) ALEIXANDRE, V. GONZÁLEZ, J.M.; RINCÓN, J.M .: Estudio de la cristalización en algunos vidrios del sistema Li ${ }_{2} \mathrm{O}-\mathrm{CdO}-$ $\mathrm{SiO}_{2}$. Bol. Soc. Esp. Ceram. Vidr. (1975)15, 23-243.

(18) RINCÓN, J.M a y GONZÁLEZ, J.M.: Effect of V205 and $\mathrm{MnO}_{2}$ additions an the crystallizations and mechanical properties of $\mathrm{Li}_{2} \mathrm{O}-\mathrm{CdO}-\mathrm{SiO}_{2}$ glasses. J. Mat. Sci. Lett. (1987) 6,1327-1330.

(19) STRNAD Z. : Glass-ceramics. ed. Elsevier, 1986.

(20) ROGERS, P.S.; WILLIAMSON, J.; JOHNSON, P.E.: United Kingdom Patent 3901716 (1975).

(21) CALLEJAS, P.; RINCÓN, J.Ma.: Microestructure and properties of new glass-ceramics form vermiculite-ambligonite. En: Ceramics Today- Tomorrws Ceramics. Part. C. Material Science Publishers B. V. (1991)1799-1806.

(22) IGONET, CH.: Les matieres premieres das vitroceramiques. Verres et Refract. (1975) 29, 4-5,177-191.

(23) JAMES, P.F.: Volumen nucleation in silicate glasses. En: Glasses and Glass-Ceramics: Cap. 3., Ed M.H. LEWIS, Chapman and Hall, (1989). London.

(24) TSUETKOV, A.l.: Reports of All-Union mineralogical Society. Part. 74, $\mathrm{n}^{\circ}$ 3. Akademizdat, (1945), Moscow-Leningrad.

(25) KOPECKY, L. y VOLDEN, J.: The cast basalt industry. Ann. N. Y. Acad. Sci. (1964) 1086-1105.

(26) BEALL, G.H. y RITTLER, H.L.: Basalt glass-ceramics Ceram. Bull, (1976) 55, 6, 579-582.

(27) HIDALGO,M.; CALLEJAS, P. y RINCÓN, J.Ma.: Microestructure characterization of basalt glass-ceramics. En: Ceramic Microestructure ' 86. The role of Interaces. Ed. J. Pask and A. Evans, Plenum Plubishing Corporation, (1988) Berkeley, $117-126$.

(28) RINCÓN, J.Mª: Glasses and glass-ceramics for nuclear waste management. Ed. SECV 2a edición (1991).

(29) RINCÓN, J. Ma y ROMERO, M.: Técnicas de vitrificación/ desvitrificación de residuos sólidos industriales. IntecUrbe, (1996) $42,51-53$.

(30) ROMERO, M. y RINCÓN, J.Ma : Innovación Química III (1996) 19, 65-68

(31) DE LA FUENTE, C.: Estudio físico-químico y mineralógico de las arcillas cerámicas del Bajo Ampurdán. Tesis Doctoral Universidad de Barcelona (1973)

(32) ALFONSO, P.: Mineralogía y propiedades vitrocerámicas de materiales magmáticos de Catalunya. Tesis de Licenciatura Fac. de Geología Universidad de Barcelona (1985).

(33) PÉREZ ARENCIBIA. J.C. y DE LA NUEZ, J.: Estudio de los materiales obtenidos a partir de la fusión de rocas volcánicas sálicas. Bol. Soc. Esp. Ceam. Vidr. (1990) 29,1, 29-31.

(34) VICENTE-MINGARRO, I.; CALLEJAS, P.; RINCÓN, J.Ma.: Caracterización de basaltos canarios como materia prima para la fabricación de vidrio y materiales vitrocerámicos. En: Ciencia y Tecnología de materiales Cerámicos y Vítreos. España 89. Ed. Faenza Editrice Ibérica y Soc. Esp. Ceram. Vidr. (1990). Castellón, España.

(35) VICENTE-MINGARRO, I.; CALLEJAS, P; RINCÓN, J.Ma.: Microestructura y microanálisis de fases minerales cristalizadas en vidrios, obtenidos a partir de rocas basálticas canarias Bol. Soc. Esp. Mineral. (1991)14, 95-105.

(36) VICENTE-MINGARRO, I.; CALLEJAS, P; RINCÓN, J.Ma.: TTT Behaviour and mechanical properties of glass-ceramics from alcali basaltic rocks. J. of European Ceram. Soc. (1992)

(37) VICENTE-MINGARRO, I.; CALLEJAS, P; CARDA, J.; SALES, M.; RINCÓN, J.Ma.: TEMISTEM/EDX investigation of glassceramic obtained from canarian alkalibasalt. En: Electron Microscopy EUREM'92, vol. 2: Material Science. Ed. López Galindo A.; Rodríguez-García, M.I.; Secrt. Pub. U. de Granada, (1992), 405-406.

(38) VICENTE-MINGARRO, I.; CALLEJAS, P: RINCÓN, J.Ma.: Nucleation and crystallization mechanism of glasses obtained from canarian basaltic rocks. Bol. Soc. Esp. Ceram. Vidr. (1992) 31-C, v.S, pp. 137-142.

(39) VICENTE-MINGARRO, I.; RINCÓN, J.Ma.; BOWLES, P.; RAWLINGS, R.D.; ROGERS, P.S.: Viscosity measurements on glasses obtained from alkaline volcanic rocks of the Canary Islands. Glass Technology, (1992) 33, 2, 49-52. 
(40) VICENTE-MINGARRO, I.; CALLEJAS, P; RINCÓN, J.Ma.: Materialcs sinterizados de $\mathrm{ZrO}_{2}$ /Piroxeno a partir de rocas basálticas españolas. Annais do XXXV Congreso Brasileiro de Cerámica, Vidrio e Refractario. (1991) 2, 773-778.

(41) MARTÍNEZ MANENT, R.; MARTÍNEZ, S.; GUILLEM, M.C.; TRAVERIA, A.: Application of Basalt in ceramic glazes. Basalt glazes. Br. Cream Trans. (1991) 90, 90-95.

(42) PELINO,M.; CANTALINI, C.; RINCÓN, J.Ma ; CALLEJAS, P.; GARCÍA-HERNÁNDEZ, J.E; TEJEDOR, M. y CÁCERES, $\mathrm{J}$.: Recycling of goethite wastes originated from hydrometallurgical plants for the production of glass-ceramics materials I Congreso Internacional de Química de la A N Q.U.E. (1990), pp. 169.

(43) RINCÓN, J.Mª.; CALLEJAS, P.; CÁCERES, J; GARCÍA-HERNÁNDEZ, J.E; PELINO, M. y CANTALINI, C.: Obtention of new glasses from metallurgical wastes enriched in iron oxidcs. En: Cerámica y Vidrio'91. Ed J.Ma. Rincón, F. Capel; A. Caballero: SECV, (1991), 4548.

(44) ROMERO, M.: Procesado y caracterización de nuevos vidrios y materiales vitrocerámicos obtenidos por reciclado de residuos industriales de goethita, Tesis Doctoral. Ed. Univ. de Alcalá de Henares, dic. 1995.

\section{publicación del IETCC/CSIC}

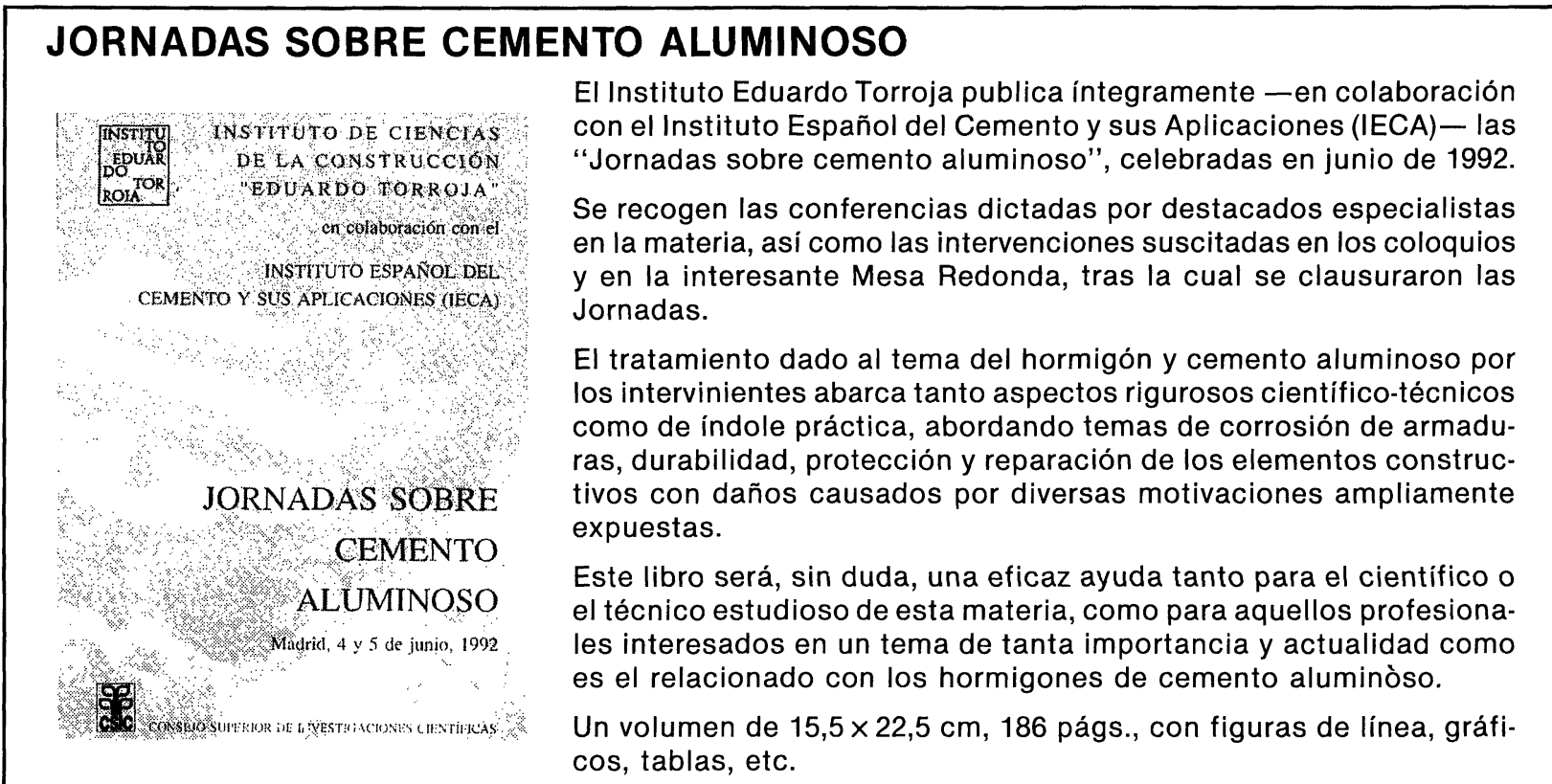

